\title{
THE TWO FACES OF A MYTH: THE FRANKENSTEIN MYTH AND ITS MYTHOLOGICAL HERITAGE
}

Talita Alves*

RESUMO: Frankenstein, escrito por Mary Shelley, remete à figura mitológica de Prometeu desde o subtítulo do romance. Frankenstein é um Prometeu moderno, ajustado aos padrões românticos da época em que foi escrito. Assim como Prometeu, Frankenstein também é o criador de um novo ser, porém sua criatura se torna um monstro incontrolável, o que evidencia a falibilidade humana. Prometeu não é o único mito usado por Mary Shelley para compor sua obra; ela também alude à história cristã da criação e queda dos homens através do épico Paraíso Perdido de John Milton. Frankenstein e sua criatura podem ser comparados a várias personagens de Paraíso Perdido em diferentes partes do romance. Apesar das alusões a Paraíso Perdido e a Prometeu, Frankenstein não é uma mera repetição destes mitos, a história de um cientista que cria um monstro se tornou um mito romântico que ainda permanece vivo no imaginário das pessoas.

PALAVRAS-CHAVE: Frankenstein, Prometeu, Paraíso Perdido, Mito.
* talitapaiva87@gmail.com

Mestranda em Literaturas de Língua Inglesa pela UFMG.

ABSTRACT: Frankenstein, written by Mary Shelley, alludes to the mythological figure of Prometheus since the subtitle of the novel. Frankenstein is a modern Prometheus, adjusted to the Romantic patterns of the time it was written. Like Prometheus, Frankenstein is also the creator of a new being; however his creature becomes an uncontrollable monster, which highlights human fallibility. Prometheus is not the only myth used by Mary Shelley to compose her work; she also alludes to the Christian story of creation and fall of mankind through John Milton's Paradise Lost. Frankenstein and his creature can be compared to several Paradise Lost's characters in different parts of the novel. Despite the allusions to Paradise Lost and Prometheus, Frankenstein is not a mere repetition of these myths, the story of a scientist who creates a monster became a Romantic myth that remains alive in people's imaginary.

KEYWORDS: Frankenstein, Prometheus, Paradise Lost, Myth. 
1. Otd. in BLOOM. Bloom's Guide, p. 18.

2. BALDICK. In Frankenstein's Shadow, p. 30
While on a visit to Lord Byron's house, Mary Shelley dreamt about a "pale student of unhallowed arts kneeling beside the thing he had put together" ${ }^{\prime}$. This is how Frankenstein was conceived. Mary Shelley's nightmare has become one of the greatest novels of the Romantic period. Its allusion to the classical epic Paradise Lost, by John Milton, combined with the archetypical figure of Prometheus composes the novel's mythological heritage. Myths are crucial elements when analyzing Frankenstein. First, they are the hypotexts of the novel. Second, Frankenstein has become a myth, a cultural icon; and it has been adapted to movies many times. According to Chris Baldick, Frankenstein "escapes Mary Shelley's textual frame and acquires its independent life outside it, as a myth" ${ }^{2}$. For instance, the name Frankenstein is usually used to designate the nameless monster rather than his creator, which may be a symptom of the detachment of the Frankenstein myth from Mary Shelley's novel. Although many people are not acquainted with the novel, the image of a scientist who creates a hideous and uncontrollable monster is undoubtedly part of their imaginary. Therefore, Frankenstein has surpassed its classical heritage to become a myth in itself as important to our society as Prometheus was to the Romantics.

To draw an analogy between Mary Shelley's text and its mythological heritage, it's important to discuss intertextuality, especially Mikhail Bakhtin's theory of dialogue and ambivalence concerning the text and its context In "Word, Dialogue and Novel", Julia Kristeva discusses this theory and explains that a text isn't an isolated work; it is oriented by a previous literary corpus, quoting and transforming other texts, as a response to them. Kristeva affirms that "each word (text) is an intersection of word (texts) where at least one other word (text) can be read"'. Bakhtin divides these words into three categories within the narrative: direct, direct-oriented and ambivalent. The last is the only one that makes it possible to use another word, or text, giving it a new meaning without losing the original meaning. Kristeva claims that "this category of ambivalent words is characterized by the writer's exploitation of another's speech ... for his own purposes", and argues that "the novel is the only genre in which ambivalent words appear"4. Based on this theory of ambivalence, we may affirm that in Frankenstein, Mary Shelley uses the myth of Prometheus and Paradise Lost in an ambivalent mode; they maintain their original meaning, but, at the same time, they acquire a specific feature that suits the novel better. For instance, the archetypical figure of Prometheus is represented by a mortal man, which changes significantly the outcome of the story. Besides, the figure of a divine creator, Prometheus in the Greek mythology or God in Milton's epic, is transformed into a fallible mortal man in the novel.
3. KRISTEVA. The Kristeva Reader, p. 37

4. KRISTEVA. The Kristeva Reader, p. 44 .

\begin{tabular}{|c|c|c|c|c|}
\hline M TESE & BELO HORIZONTE & v. 20 & N. 2 & MAIO-AGO. 2014 \\
\hline
\end{tabular}

Crítica Literária, outras Artes e Mídias 
5. FRYE. Biblical and Classical Myths, p. 275.

6. FRYE. Biblical and Classical Myths, p. 275.

7. For further information, see Julio Jeha's Das Origens do Mal.

8. See Hemingway's interview in The Norton Anthology of Short Fiction (BAUSH, 858)
In Biblical and Classical Myths, Northrop Frye defines myth as "a Greek word meaning story, especially a story about gods and heroes"5. He also affirms that the plot of these stories may vary throughout time and space since there is no written collection of them. Moreover, Frye explains that some people believe myths are stories about true "moral men remembered after their death for remarkable deeds"6; others find in myths explanations of natural events and unknown historical facts. However, Frye dismisses the idea that myth are intended to have a moral. He points out that most of the gods and heroes in those stories have an amoral behavior Interestingly, Frye's observation on mythical characters can be applied to Frankenstein since there aren't morally good round characters in the novel. In addition, Mary Shelley's novel is open to a couple of different interpretations. For instance, Frankenstein is widely known as the product of Mary Shelley's nightmare, yet some people argue that she wrote the novel as a critique to Jean Jacques Rousseau ${ }^{7}$. Other people may affirm that Frankenstein is intended to have a moral However, I prefer Ernest Hemingway's idea that although a book is not written to have a moral, it may be instructive ${ }^{8}$.

To study myths in relation to Mary Shelley's novel, it's important to mention the concept of archetypes. In The Concise Oxford Dictionary of Literary Terms, Chris Baldick defines archetype as a symbol or character type "that recurs in different times and places in myth, literature, folklore, dreams and rituals". Prometheus, the pagan version of man's creator, was one of the favorite archetypes of the Romantics. Many poets, such as Percy Shelley and Lord Byron, wrote about this Titan who stole fire from the gods and gave it to humankind. According to Harold Bloom, Prometheus was their favorite hero because "no other traditional being has in him the full range of Romantic moral sensibility and the full Romantic capacity for creation and destruction" ${ }^{10}$. Similarly, Frankenstein is seen as the story of this brilliant human being who has symbolically stolen godlike knowledge in order to generate a new species. It represents creation and destruction at the same time.

When an archetype is used, intentionally or not, by a writer, it becomes a new character, theme or place. For instance, Mary Shelley subtitled her novel Frankenstein as the Modern Prometheus. Nevertheless, Frankenstein isn't a mere copy of this mythological story; it has a new plot, setting and themes. In Anatomy of Criticism, Northrop Frye proposes that "... what can be metaphorically identified in a myth can only be linked in romance by some form of simile: analogy, significant association..." ${ }^{\prime 1}$. When Shelley adds the word Modern to the archetype, she probably wants to emphasize the difference between them. Frankenstein follows a mythic pattern, but it is completely new in the sense that it is about "the Modern Prometheus", in contrast to the so-called original one. Like Prometheus, Frankenstein overcomes his limits to
9. BALDICK. The Concise Oxford Dictionary of Literary Terms, p. 19.

10. BLOOM. Modern Critical Interpretation, p. 2.

11. FRYE. Anatomy of Criticism, p. 137.

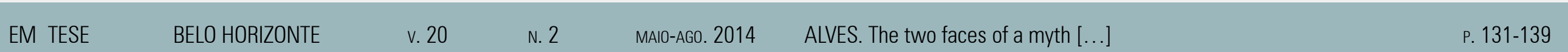


12. SHELLEY, Frankenstein, p. 64

13. SHELLEY, Frankenstein, p. 64.

14. GILBERT. The Madwoman in the Attic, p.230.

15. SHELLEY. Frankenstein, p. 155. be able to help human beings; at least it is what Frankenstein intends at first; he says: "Life and death appeared to me deal bounds, which I should first break through, and pour a torrent of light into our dark world"12. Frankenstein wants to discover a solution for humans' most dreadful fear: death. He believes he can "renew life where death had apparently devoted the body to corruption"13. His intentions are good, but his creation goes wrong and becomes the opposite of what Frankenstein wishes; the monster spreads death wherever he goes.

Another important hypotext of Frankenstein is Milton's Paradise Lost for it represents the Christian version of the creation of man. An analogy between Paradise Lost's characters and Frankenstein's helps readers understand their roles in the novel. Interestingly, this analogy is not fixed; it is interwoven in a complex web since Frankenstein's characters assume different Miltonic roles throughout the novel; "Frankenstein is ultimately a mock Paradise Lost in which Victor and his monster ... play all the neo-biblical parts over and over again" ${ }^{14}$. The Creature can be related to Adam, Eve and Satan, whereas Frankenstein may be compared mainly to God, Adam and Satan. For instance, the Creature resembles Adam since he is the first of his kind; he is "apparently united by no link to any other being in existence" 15 . He is also like Eve in a very specific moment of the novel when he sees himself through a pool. In contrast to Eve, who looks at the water and gets surprised by her own beauty, the Creature gets terrified by his ugliness ${ }^{16}$. Afterwards, he becomes a Satan figure for his cruelty to Victor and his beloved family and friends. Likewise, Victor starts the novel as Adam for he also wants to discover the secrets of the world. Then, he becomes a God figure; he succeeds in "bestowing animation upon lifeless matter" ${ }^{\prime 7}$, although this experiment has disastrous consequences. Finally, he resembles Satan for he also envies God when he wishes to be the creator of a new species.

Moreover, Mary Shelley borrows Milton's concept of Paradise Within and, paradoxically, has her characters experience a Hell Within. For instance, in Paradise Lost, Satan declares that "the mind is its own place, and itself can make a Heaven of Hell, a Hell of Heaven"18, which emphasizes the idea that living in a paradise, or a hell, depends on each one's mind; it's a matter of choice. In Frankenstein, the Creature puts himself on the same level as Satan when he chooses to hunt Victor down and make him suffer. He lets behind all the possibilities of being good, and becomes more uncontrollable after each murder he commits. Besides, the Creature's hellish condition is intensified through loneliness, which seems his greatest fear ${ }^{19}$. He attempts to be accepted into De Lacey's family; but, as he is rejected, he goes after his
16. OATES. Frankenstein's Fallen Angel, p. 547 .

17. SHELLEY. Frankenstein, p. 62.

18. MILTON. Paradise Lost, I 254-255.

19. POLLIN. Philosophical and Literary Sources of Frankenstein, p. 104.

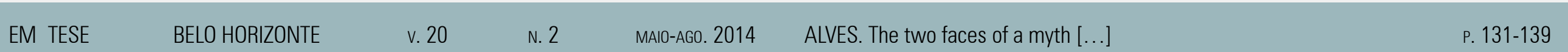

\section{Crítica Literária, outras Artes e Midias}


20. SHELLEY. Frankenstein, p. 172.

21. SHELLEY. Frankenstein, p. 267.

22. BALDICK. In Frankenstein's Shadow, p. 2. creator to request a companion "as deformed and horrible as" ${ }^{20}$ him. At first, Frankenstein agrees to help the monster but he ends up destroying the other creature before he finishes it. Thus, the monster is condemned to loneliness again, and, after Frankenstein's death, the Creature doesn't see any reason to continue living and condemns himself to experience a real hellish ending; he says: "I shall ascend my funera pile triumphantly, and exult in the agony of the torturing flames"21. Even his final moment of life alludes to Satan and his eternal lost condition. In Mary Shelley's novel, Paradise Lost's archetypes are invoked to establish a contrast between her characters' experiences and the ideal paradise.

Undoubtedly, the mythological and the literary references transformed Mary Shelley's nightmare into a recognized literary text. They enabled Frankenstein to have a meaning in itself and become a Romantic myth. Chris Baldick explains that "a literary text will usually ... be fixed in its form but may be complex and multivocal in its meaning. A myth, on the other hand, is open to all kinds of adaptation and elaboration, but it will preserve at the same time a basic stability of meaning"22. Thus, Mary Shelley's appropriation of the myths doesn't change their "original meaning"; it gives them another interpretation more suitable to the new context. For instance, the allusion to Prometheus fits Frankenstein very well, but the tools used to accomplish his purpose are completely different from Prometheus'. Baldick claims, "the vitality of myths lies precisely in their capacity for change, their adaptability and openness to new combinations of meaning"23. This capacity is found not only in the mythological references, but in the novel itself. Therefore, all the adaptations, allusions and parodies which follow Frankenstein "[are] not just a supplementary component of the myth; it is the myth"24. It explains why Frankenstein's monster is known even by the people who have never heard of Mary Shelley's novel.

Frankenstein's mythological background placed Mary Shelley's novel among the most memorable myths of all times. Though Frankenstein is a Romantic adaptation of Prometheus, "the Frankenstein legend retains a significance for our time as the Prometheus legend does not"25. Joyce Carol Oates affirms, Frankenstein has "made the great leap from literature to mythology" and stepped into "a collective cultural consciousness" ${ }^{\prime 2}$. Fictional characters, such as Don Quixote, Dracula, Sherlock Holmes, Alice (in Wonderland) and Frankenstein's monster, have been detached from the authors and become "communal creations" 27 . Few people have read their books, but everyone knows their stories. Oates also affirms, "the more potent the archetype evoked by a work of literature, the more readily its specific form slips free of the time-bound personal work" ${ }^{28}$, which might explain why Frankenstein, the novel written by Mary Shelley, isn't as popular as its movie adaptations. Most of the people
23. BALDICK. In Frankenstein's Shadow, p. 4.

24. BALDICK. In Frankenstein's Shadow, p. 4.

25. OATES. Frankenstein's Fallen Angel, p. 548.

26. OATES. Frankenstein's Fallen Angel, p. 548.

27. OATES. Frankenstein's Fallen Angel, p. 549.

28. OATES. Frankenstein's Fallen Angel, p. 549.

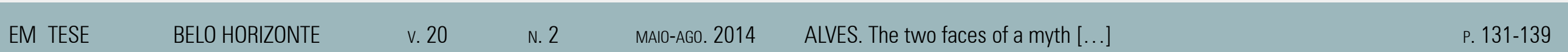

\section{Crítica Literária, outras Artes e Midias}


29. RAJEWSKY. Intermediality, Intertextuality, and Remediation, p. 51.

30. RAJEWSKY. Intermediality, Intertextuality, and Remediation, p. 52-53.

31. SANDERS. Adaptation and Appropriation, p. 20. who know Frankenstein's story have watched at least one of the several adaptations, but few of them have read the novel.

To analyze Frankenstein as a myth, it is necessary to consider Irina O. Rajewsky's concepts of medial transposition and intermedial reference. Rajewsky defines medial transposition as "the transformation of a given media product (a text, a film, etc.) or of its substratum into another medium" ${ }^{29}$. As for intermedial references, she defines them as strategies that "contribute to the media product's overal signification: the media product uses its own media-specific means ... to refer to a specific, individual work produced in another medium"30. An example of a medial transposition is the movie produced by James Whale in 1931, which is an adaptation of the novel to cinema. According to Julie Sanders, "... all screen versions of novels are transpositions in the sense that they take a text from one genre and deliver it to new audiences by means of the aesthetic conventions of an entirely different generic process..."31. Although severa details were changed, such as names and the ending, and some events were edited out, Mary Shelley's story remains the source of the screenplay, which sustains the idea that it is a medial transposition.

It is also possible to find visual allusions to Frankenstein that don't follow the novel's plot closely; one of them is the TV series Once Upon a Time. It is not a medial transposition since it doesn't retell the novel word by word; it is rather an intermedial reference because it alludes to Frankenstein with some variations. This TV series appropriates the story of Frankenstein and his monster and transforms it into a new story maintaining the main concept, the archetype. According to Sanders, adaptations may "constitute a simpler attempt to make texts 'relevant' or easily comprehensible to new audiences" ${ }^{\prime 2}$, which explains the several changes made by the series authors in order to incorporate Frankenstein into the world of fairy tales. Sanders also observes that ".. a myth is never transported wholesale into its new context; it undergoes its own metamorphoses in the process" ${ }^{\text {"3 }}$. Therefore, all the alterations serve to adapt Frankenstein to this new generation that seems not to be used to reading the classics or old bedtime stories. The changes are also important to link Frankenstein, a literary character, to all those fairy tale characters and to support the idea that they may be part of the same realm, the fictional world. Thus, Once Upon a Time becomes a retelling of all those stories we usually heard when we were kids; but, now, they are changed so that they can be interesting to a new kind of audience. It is also interesting to notice that Frankenstein's land is in black and white, which may be an intramedial reference to the Frankenstein black and white movies. In sum, the series refers to both the novel and the movies, for it hints at the novel and imitates the style of the 1931 movie.
32. SANDERS. Adaptation and Appropriation, p. 19.

33. SANDERS. Adaptation and Appropriation, p. 64

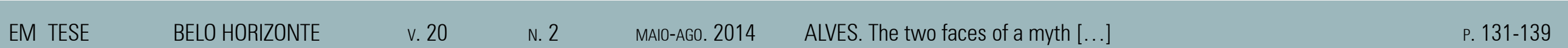

Critica Literária, outras Artes e Mídias 
The story of Frankenstein is first mentioned on the fifth episode of the second season, named The Doctor. Dr Whale, Frankenstein's name in Storybrooke, a fictional city in Maine, remembers his past and urges Regina, the Evil Queen, to send him back to his land because he wants to bring his brother back to life. As Regina refuses, Dr. Whale brings Regina's dead fiancé, Daniel, back to please her so that she would help him. However, it proves to be a terrible idea, as Daniel is not the same person anymore; he is impulsively violent and he is unable to control himself. In the end, Regina is obliged to kill Daniel and forget him definitely. Thus, in the series, Frankenstein is a doctor who is able to bring dead people to life, but, as in the novel, this new being is violent and uncontrollable. The archetypical figure of a scientist and his monster remains basically the same. While this story is told, another one is shown to the spectators. Back in the Enchanted Forest, Regina meet Jefferson, also known as the Mad Hatter, who tells her about this doctor from another land who can bring dead people to life. Then, Frankenstein comes to the Enchanted Forest to revive Daniel, but what he really wants is to get one of the magical hearts from the Enchanted Forest so that he can try the procedure in his brother. In the end, he deceives Regina, comes back to his land, and revives his brother. Although there are many differences, it is certainly an adaptation of Mary Shelley's novel since the series alludes to Frankenstein and his object of study: giving life to dead bodies. However, no other character from the novel is mentioned, except for Frankenstein's father and brother, whose characteristics are also changed. For instance, Frankenstein's brother, William, is a young boy in the novel, but in the series he is Gerhardt, a grown-up soldier.

There is another episode dedicated to Frankenstein. It is the twelfth episode of the second season as well; it's named In the Name of the Brother. Most of the episode is a flashback that tells the beginning of Frankenstein's life. As in the novel, Victor Frankenstein has lost his mother, but he still has his father and his younger brother. In the series, Victor's father doesn't understand his son's research and decides to stop financing him. He wants Victor to join the Army instead. In contrast to his father, Gerhardt always supported his brother. However, Gerhardt starts questioning Victor's research when he sees his brother stealing a corpse from a grave. While they are arguing, a guard arrives and starts shooting at them. Gerhardt gets injured and dies. From then on, Victor intensifies his research in order to bring his brother back. After several frustrating attempts, he receives the visit of Rumplestiltskin, the Dark One, who tells him that in his land there are hearts that would stand the procedure. He just succeeds after he gets a magical heart, but Gerhardt is not the same anymore. He is so violent and out of control that he kills his own father.

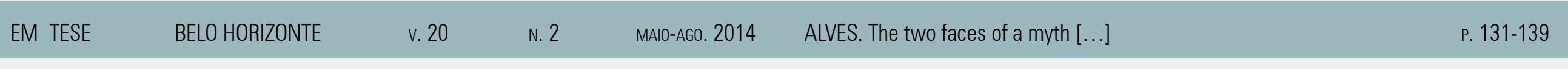

\section{Crítica Literária, outras Artes e Midias}


34. FRYE. Biblical and Classical Myths, p. 277.

35. FRYE. Biblical and Classical Myths, p. 277.
According to Frye, science fictions, such as Frankenstein are "startlingly close to fairy tale and myth" for they usually portray "heroes with lesser but still superhuman powers" 34 Although Frankenstein's setting is our ordinary world, his discovery of the secret of life is his superhuman power. Frye also argues;

Myth is the most ancient kind of story-telling; and these tales from ancient Greece and Rome, along with those of the Bible and the later European folk tales like those collected in Germany by the brothers Grimm, remain the basis of our fiction. There are really very few stories, as we must all have thought at the movies. Or rather, there are any number of stories, but they are all based on a few kinds of plot: narratives of creation, transformation, and destruction, of love, loss, revenge, of friendship and conflict, of quest and disappointment and success ${ }^{35}$.

In Mary Shelley's novel there are hints of the Greek myth of Prometheus, allusions to Paradise Lost, a literary interpretation of the first chapters of the Bible; and finally, as one of the hypotexts of Once Upon a Time, the Frankenstein myth may be related to folk tales, as if Frankenstein were part of our oral tradition.

In conclusion, Sanders argues that "...mythical literature depends upon, incites even, perpetual acts of reinterpretation in new contexts, a process that embodies the very idea of appropriation" ${ }^{36}$. When Mary Shelley wrote Frankenstein, she appropriated the myth of Prometheus and Paradise Lost and adapted them to a new context and audience, making the classics suitable to a Romantic reader. Now Frankenstein has been adapted to the movies and TV so that it continues in people's imaginary. As for the changes of characters and plot, they are often necessary to make an old story fit into a new context. According to Baldick, "most myths ... prolong their lives not by being retold at great length, but by being alluded to, thereby finding fresh contexts and applications"37. The fact that Frankenstein, as the myth of Prometheus, may be re-viewed reinforces the idea that it has become a myth as important to our society as Prometheus was to the Romantics. It doesn't matter if the story is going to be faithful to Mary Shelley's novel provided that the Frankenstein myth remains alive.

\section{REFERENCES}

Baldick, Chris. In Frankenstein's Shadow: myth, monstrosity, and nineteenth-century writing. Oxford: Charendon Press, 1987.

\section{---. The Concise Oxford Dictionary of Literary Terms. Oxford:} Oxford U P, 2001.

Baush, Richard. R.V. Cassill. The Norton Anthology of Short Fiction. Shorter Seventh Edition. New York: W.W. Norton \& Company, 2006.
36. SANDERS. Adaptation and Appropriation, p. 63.

37. BALDICK. In Frankenstein's Shadow, p. 3.
EM TESE
BELO HORIZONTE
v. 20
N. 2
MAIO-AGO. 2014 
Bloom, Harold. Introduction. Bloom's Modern Critical

Interpretations: Mary Shelley's Frankenstein. Ed. Harold Bloom.

Updated Edition, New York: Chelsea House. 2007. 1-11.

--. Bloom's Guide: Mary Shelley's Frankenstein. New York: Infobase Publishing, 2007.

FRANKENSTEIN. Dir. James Whale. United States: Universal Pictures, 1931

Frye, Northrop. Anatomy of Criticism. New Jersey: Princeton U P. 2000

Frye, Northrop, Jay Macpherson. Biblical and Classical Myths Toronto: Toronto U P, 2004

Gilbert, Sandra M., and Susan Gubar. The Madwoman in the Attic: The Woman Writer and the Nineteenth-Century Literary Imagination. New Haven: Yale University Press, 1984.

Jeha, Julio. Das origens do mal: a curiosidade em Frankenstein. In: JEHA, Julio, e Lyslei Nascimento. Da fabricação de monstros. Belo Horizonte: Editora UFMG, 2009. 11-23.

Kristeva, Julia. "Word, Dialogue and Novel". The Kristeva

Reader. Ed. Toril Moi. New York: Columbia University Press, 1986. 34-61.

"In the Name of the Brother". Once Upon a Time. ABC. 20/01/2013

Milton, John. Paradise Lost. Ed. William Kerrigan, John Rumrich and Stephen M. Fallon. New York: Modern Library, 2008.
Oates, Joyce Carol. Frankenstein's Fallen Angel. Critical Inquiry, $10.3,543-554,1984$

Pollin, Burton R. Philosophical and Literary Sources of Frankenstein. Comparative Literature, 17.2, 97-108, 1965.

Rajewsky, Irina O. Intermediality, Intertextuality, and Remediation: A Literary Perspective on Intermediality. Intermédialités, 6 , Automne, 43-64, 2005

Sanders, Julie. Adaptation and Appropriation. London: Routledge, 2006.

Shelley, Mary. Frankenstein. London: Collector's Library, 2004.

"The Doctor". Once Upon a Time. ABC. 28/10/2012.

\section{Crítica Literária, outras Artes e Mídias}

